\title{
Geotrichum infection in an immunocompetent host with SARS-CoV-2 infection
}

\author{
Kavitha SELVAN(ID) \\ Gökhan MUTLU(ID)
}

Cite this article as: Selvan K, Mutlu G. Geotrichum infection in an immunocompetent host with SARS-CoV-2 infection. Tuberk Toraks 2021;69(3):421-424.

\section{Address for Correspondence (Yazışma Adresi)}

\section{Dr. Gökhan MUTLU}

Section of Pulmonary and Critical Care Medicine, University of Chicago, CHICAGO - UNITED STATES OF AMERICA e-mail: gmutlu@uchicago.edu

CCopyright 2021 by Tuberculosis and Thorax

Available on-line at www.tuberktoraks.org.com
Section of Pulmonary and Critical Care Medicine, University of Chicago, Chicago, United States of America

Chicago Üniversitesi, Göğüs Hastalıkları ve Yoğun Bakım Bölümü, Şikago, Amerika Birleşik Devletleri

\begin{abstract}
Geotrichum infection in an immunocompetent host with SARS-CoV-2 infection

There has been increasing reports of secondary bacterial and fungal infections associated with COVID-19. Following the initial reports of infection with Aspergillus spp., and Candida spp. there has been a significant rise in infections with Mucorales spp. In this case report, we present a case of Geotrichum spp. infection in an immunocompetent host with COVID-19. To our knowledge, this is the first case of Geotrichum infection in COVID-19. Geotrichum is a rare emerging pathogen that causes invasive disease, termed geotrichosis, which occurs in immunocompromised adult hosts with neutropenia. The development of invasive fungal infection such as Geotrichum in patients with SARS-CoV-2 infection requires a high degree of clinical suspicion and should be considered particularly in those who have an underlying immunocompromised state and those receiving corticosteroids or other immunosuppressive agents.
\end{abstract}

Key words: COVID-19; SARS-CoV-2; immunosuppressive agents; fungal; Geotrichum

ÖZ

SARS-CoV-2 enfeksiyonlu bağışıklığı sağlam bir hastada Geotrichum enfeksiyonu

COVID-19 ile ilişkili sekonder bakteriyel ve fungal enfeksiyonlara ilişkin raporlar gün geçtikçe artmaktadır. Aspergillus spp. ve Candida spp. ile enfeksiyonların, olguların tarif edildiği ilk raporlarının ardından Mucorales spp. ile enfeksiyonlarda önemli bir artış olmuştur. Bu olgu sunumunda COVID-19 olan bağışıklığı sağlam bir hastada Geotrichum spp.'ye bağlı enfeksiyonu bildiriyoruz. Bildiğimiz kadarıla, bu COVID-19'daki ilk Geotrichum enfeksiyonu vakasıdır. Geotrichum, bağısııkı̆̆g baskılanmış ve özellikle nötropenili hastalarda ortaya çıkan, geotrikoz olarak adlandırılan invaziv hastalığa neden olan, nadir ortaya çıkan bir patojendir. SARS-CoV-2 enfeksiyonlu hastalarda Geotrichum gibi invaziv mantar enfeksiyonu gelişimi, yüksek derecede klinik şüphe gerektirir ve özellikle altta yatan bir bağışıklık sistemi baskılanmış durumu olanlarda ve kortikosteroidler veya diğer bağısııklık bastırıcı ajanlar alan hastalarda düşünülmelidir.

Anahtar kelimeler: COVID-19; SARS-CoV-2; bağışıklık baskılayıIı ilaçlar; fungal; Geotrichum 


\section{INTRODUCTION}

There has been an increasing number of fungal infections reported in patients with COVID-19 (1-3). The most commonly reported pathogens include Aspergillus spp., Candida spp., and more recently, Mucorales spp. $(1,2)$. In fact, during the second wave of COVID-19 in India, there has been a significant rise in cases of mucormycosis (3). While it is not clear whether these fungal infections are due to COVID-19 or occur as a complication of treatment with immunosuppressive agents, the development of fungal infections represent another challenge complicating the management and likely outcome of patients with COVID-19. Here, we present a case of Geotrichum spp. infection in an immunocompetent host with COVID-19.

\section{CASE}

A 50-year-old man with history of type 2 diabetes mellitus presented as a transfer to the medical intensive care unit (MICU) of a tertiary care center with acute respiratory distress syndrome (ARDS). He initially presented to a local emergency department 22 days prior to transfer with fevers, chills, and muscle aches and was found to be PCR positive for SARSCoV-2. He was admitted to a general medicine service and started on dexamethasone and remdesivir. Due to progressive hypoxemic respiratory failure, he required transfer to the MICU and was ultimately intubated on hospital day 17. Over the course of his hospitalization, he received treatment with convalescent plasma, tocilizumab, baricitinib, anakinra, $\mathrm{N}$-acetylcysteine, vitamin $\mathrm{C}$, and zinc. Despite these therapies, he remained severely hypoxemic and was transferred to our institution for consideration of extracorporeal membrane oxygenation (ECMO).

Upon arrival to our MICU, he was afebrile and hemodynamically stable, mechanically ventilated on assist-control volume-control $(\mathrm{AC}-\mathrm{VC})$ with the following settings: tidal volume $330 \mathrm{cc}(6 \mathrm{cc} / \mathrm{kg}$ IBW), respiratory rate 30 breaths/minute, fraction of inspirated oxygen $\left(\mathrm{FiO}_{2}\right)$ 0.6, positive end-expiratory pressure (PEEP) $5 \mathrm{~cm} \mathrm{H}_{2}$ O. Arterial blood gas showed $\mathrm{pH}$ 7.37, $\mathrm{pCO}_{2} 82 \mathrm{mmHg}$, and $\mathrm{pO}_{2} 88 \mathrm{mmHg}$. An endotracheal aspirate was collected on admission.

Four days after arrival, he developed fever and was empirically started on vancomycin and cefepime. Five days after arrival, his admission endotracheal aspirate returned positive for filamentous fungi that ultimately speciated to Geotrichum spp., and voriconazole was initiated. Antimicrobial sensitivity testing showed sensitivity to both azoles and polyenes (Table 1). Despite aggressive fluid resuscitation and treatment with antimicrobial drugs, the patient did not improve and developed refractory septic shock requiring treatment with multiple vasopressors and severe mixed acidosis requiring continuous renal

Table 1. Geotrichum spp. sensitivities

\begin{tabular}{|lc|}
\hline Antifungal & Concentration $(\mu \mathrm{g} / \mathrm{ml})$ \\
\hline Amphotericin B & 1 \\
Fluconazole & 32 \\
Voriconazole & 0.5 \\
Posaconazole & 1 \\
\hline
\end{tabular}

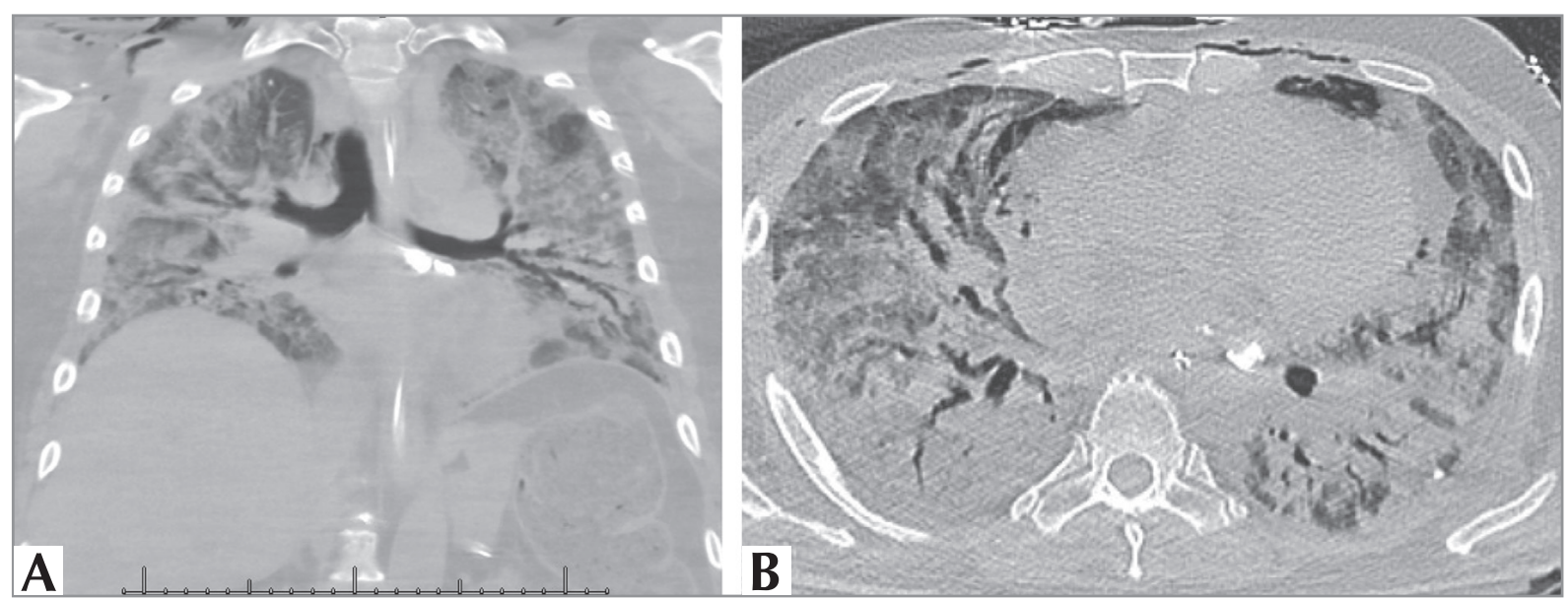

Figure 1. A. High-resolution CT (HRCT) images in coronal and B. Axial planes showing bilateral ground glass opacities with traction bronchiectasis. 
replacement therapy (CRRT). After discussion with family, the decision was made to transition to comfort-focused care, and the patient ultimately passed away 11 days after arrival.

\section{DISCUSSION}

There has been a growing body of literature describing fungal infection in patients with COVID-19. A 2020 study from China reported five cases of fungal infection (one case of Aspergillus flavus and four cases of Candida spp.) identified in a cohort of 99 patients with SARS-CoV-2 infection, and more recent studies have reported increased rates of coronavirus-associated pulmonary aspergillosis in severely-ill, mechanically ventilated patients, ranging from 3.8 to $34 \%(1,2)$. More recently, India has reported an alarming number of COVID-19-associated mucormycosis cases, accounting for approximately $71 \%$ of global cases reported between December 2019 and April 2021 (3). Risk factors identified for the development of invasive fungal disease include advanced age, hypertension, underlying pulmonary disease, uncontrolled diabetes, use of corticosteroids, prolonged ICU stays, and severe SARS-CoV-2 infection (2-5). Additionally, the use of non-corticosteroid immunosuppressive agents may also represent a risk factor for invasive fungal infection $(6,7)$. An observational cohort study found that tocilizumab, an IL-6 receptor antagonist, was associated with an increased risk of invasive fungal infection in patients with severe COVID-19 receiving renal replacement therapy, prompting the American Thoracic Society to publish a practice update urging caution with its use (6).

Here, we described a case of Geotrichum spp. infection in a middle-aged man with SARS-CoV-2 infection. To our knowledge, this is the first case of Geotrichum infection in COVID-19. The genus Geotrichum encompasses several species of saprophytic yeast that are found in nature and colonize the human skin, respiratory, and gastrointestinal tracts (8). It is a rare emerging pathogen that causes invasive disease, termed geotrichosis, in immunocompromised adult hosts, and infection is most commonly associated with neutropenia secondary to the administration of chemotherapy (9). Even more rare is the development of bronchopulmonary geotrichosis, of which there are only a handful of case reports described in the literature, all of which occurring in patients with underlying chronic lung disease or can- cer (10). Trauma and burn injuries are the only predisposing factors that have been described in the literature for the development of geotrichosis in immunocompetent individuals (11-13).

While our patient was not classically immunocompromised, he did have several risk factors that may have contributed to the development of pulmonary geotrichosis. On admission, his HbA1c was 9.1\% indicating poor control of his diabetes mellitus; however, the majority of reported cases of geotrichosis in this population have been limited to oral, urinary, or rarely, cutaneous involvement (14-16). Additionally, he received multiple immunosuppressive agents during his hospitalization as part of his treatment for severe SARS-CoV-2 infection, including high-dose corticosteroids and tocilizumab, both of which may have led to increased susceptibility to fungal infection. Lastly, there is emerging evidence that in hospitalized COVID-19 patients develop dysbiosis characterized by alterations in fecal bacterial and fungal microbiota with enrichment of Candida and Aspergillus species $(17,18)$ which may lead to an increased susceptibility for fungal infections. Further studies are needed to determine whether changes in microbioata may play a role in the increased fungal infection in patients with COVID-19.

The development of invasive fungal infection in patients with SARS-CoV-2 infection can be difficult to identify and requires a high degree of clinical suspicion. Bronchopulmonary geotrichosis should be considered in patients with severe COVID-19, particularly in those who have an underlying immunocompromised state and those receiving corticosteroids or other immunosuppressive agents.

\section{CONFLICT of INTEREST}

The authors reported no conflict of interest related to this article.

\section{AUTHORSHIP CONTRIBUTIONS}

Concept/Design: KS, GMM

Analysis/Interpretation: KS, GMM

Data Acquisition: KS

Writing: KS, GMM

Critical Revision: KS, GMM

Final Approval: KS, GMM 


\section{REFERENCES}

1. Chen N, Zhou M, Dong X, Qu J, Gong F, Han Y, et al. Epidemiological and clinical characteristics of 99 cases of 2019 novel coronavirus pneumonia in Wuhan, China: a descriptive study. Lancet 2020; 395: 507-13.

2. Marr KA, Platt A, Tornheim JA, Zhang SX, Datta K, Cardozo C, Garcia-Vidal C. Aspergillosis Complicating Severe Coronavirus Disease. Emerging infectious diseases 2021; 27.

3. Raut A, Huy NT. Rising incidence of mucormycosis in patients with COVID-19: another challenge for India amidst the second wave? Lancet Respir Med 2021.

4. John TM, Jacob CN, Kontoyiannis DP. When Uncontrolled Diabetes Mellitus and Severe COVID-19 Converge: The Perfect Storm for Mucormycosis. J Fungi (Basel) 2021; 7.

5. Witting C, Quaggin-Smith J, Mylvaganam R, Peigh G, Angarone M, Flaherty JD. Invasive pulmonary aspergillosis after treatment with tocilizumab in a patient with COVID19 ARDS: a case report. Diagn Microbiol Infect Dis 2021; 99: 115272

6. Burger BJ, Epps SM, Cardenas VM, Jagana $R$, Meena NK, Atchley WT. Tocilizumab is associated with increased risk of fungal infections among critically ill patients with COVID-19 and acute renal failure: an observational cohort study. Research Square 2021.

7. Kimmig $L M, W u D$, Gold M, Pettit NN, Pitrak D, Mueller J, et al. IL-6 Inhibition in Critically III COVID-19 Patients IS Associated With Increased Secondary Infections. Front Med (Lausanne) 2020; 7: 583897.

8. Sheehy TW, Honeycutt BK, Spencer JT. Geotrichum septicemia. JAMA 1976; 235: 1035-7.

9. Duran Graeff L, Seidel D, Vehreschild MJ, Hamprecht A, Kindo A, Racil Z, et al. Invasive infections due to Saprochaete and Geotrichum species: Report of 23 cases from the FungiScope Registry. Mycoses 2017; 60: 273-9.
10. Winer-Muram HT. Geotrichosis: who is susceptible? Chest 1988; 94: 1315-6.

11. Radic M, Goic Barisic I, Kuscevic D, Novak A, Tonkic M, Rubic Z. Geotrichum capitatum respiratory tract infection in a patient with polytrauma. Infez Med 2015; 23: 270-4.

12. Hrdy DB, Nassar NN, Rinaldi MG. Traumatic joint infection due to Geotrichum candidum. Clinical infectious diseases : an official publication of the Infectious Diseases Society of America 1995; 20: 468-9.

13. Keene S, Sarao MS, McDonald PJ, Veltman I. Cutaneous geotrichosis due to Geotrichum candidum in a burn patient. Access Microbiol 2019; 1: e000001.

14. Bilman FB, Yetik M. Geotrichum candidum: A Rare Infection Agent in Urinary System: Case Report and Review of The Literature. I Clin Exp Invest 2017; 8: 127-9.

15. Sfakianakis A, Krasagakis K, Stefanidou M, Maraki S, Koutsopoulos A, Kofteridis D, et al. Invasive cutaneous infection with Geotrichum candidum: sequential treatment with amphotericin B and voriconazole. Med Mycol 2007; 45: 81-84.

16. Bonifaz A, Vazquez-Gonzalez D, Macias B, ParedesFarrera F, Hernandez MA, Araiza J, et al. Oral geotrichosis: report of 12 cases. J Oral Sci 2010; 52: 477-83.

17. Zuo T, Zhang F, Lui GCY, Yeoh YK, Li AYL, Zhan H, et al. Alterations in Gut Microbiota of Patients With COVID-19 During Time of Hospitalization. Gastroenterology 2020; 159: 944-55.

18. Zuo T, Zhan H, Zhang F, Liu Q, Tso EYK, Lui GCY, et al. Alterations in Fecal Fungal Microbiome of Patients With COVID-19 During Time of Hospitalization until Discharge. Gastroenterology 2020; 159: 1302-10. 